\title{
WHO GRADUATES FROM IRISH DISTANCE UNIVERSITY EDUCATION?
}

\author{
Lorraine Delaney [lorraine.delaney@dcu.ie], Open Education Unit, National Institute for Digital Learning, \\ Dublin City University, Ireland
}

\begin{abstract}
This paper outlines results from an online survey of recent distance graduates. The study, based in Dublin City University (DCU) addresses a gap in the research on this cohort of graduates. Findings indicate that distance graduates are primarily from lower socio economic backgrounds, a group largely under-represented in full-time university education. Significantly, 30\% of survey respondents came from a skilled manual background. A large percentage $(39 \% \mathrm{~N}=61)$ of graduates had never accessed any form of higher education before. An equally large percentage $(\mathrm{N}=62)$ had accessed full-time higher education previously, but at a lower level than the honours primary degree they obtained through distance learning. Implications regarding the role of distance education in improving access to university education and social mobility are discussed. Finally, this paper seeks to establish relevance between knowledge of distance graduates and doing things better for first time distance learners.
\end{abstract}

Keywords: access; graduates; distance education; participation.

\section{Introduction}

The purpose of this research is to explore the role played by online distance education in broadening access to Irish university education. The concept of access is now understood 'to encompass not only entry to higher education, but also retention and successful completion' (EAN, 2015; HEA, 2008, p.14). For this reason the focus of this paper is on graduates. The main questions explored in this paper are:

1. Are distance graduates new to university education?

2. Are distance graduates from groups who are under-represented in university education?

Graduate data has the potential to positively affect programme evolution and policy development in relation to higher education access. However, because distance education is not publically funded in Ireland, no official data is gathered on distance graduates. If we don't know who distance graduates are, we cannot know whether distance education is broadening or deepening access to university education to a new or diverse student population. Neither can we know whether it is impacting positively on the social mobility of this group. Additionally, important information regarding the educative experience remains unknown.

Graduates are in the unique position of being able to judge the impact of their qualification on their work and personal lives. Additionally, they are well placed to evaluate their overall educative experience. For this reason knowing our graduates positions us to understand the student experience and do things better for future distance learners.

The graduates in this study are not representative of all online distance graduates in Ireland. The intention of the study is not to generalise findings but rather to provide a unique insight and interpretation of a phenomenon in one particular case (Merriman, 1988). Therefore findings are 
suggestive. To date, no study has explored the particular position of online distance university graduates in an Irish context.

\section{Background and context}

Dublin City University (DCU) has been providing distance education since 1982. In that time, over 5,500 distance students have graduated. By way of comparison, the DCU Access service has graduated 600 students over 21 years (DCU Access Report, 2011). Both services seek to broaden access to Irish higher education; the Access service seeks to accommodate those who can attend university full-time but would be highly unlikely to do so if not financially supported. Distance education, on the other hand, accommodates those who are in a position to pay fees but not in a position to attend. For those who can neither attend nor pay fees limited funding is available in Ireland under the Springboard initiative. Springboard targets the unemployed and funds specific courses which aim to provide students with identifiable skills required in the labour market. The courses are normally of one year, part-time duration.

In its consultation paper on Part-time higher education and training in Ireland, the Higher Education Authority (HEA) states that if Ireland is to increase higher education attainment, increased flexibility and broader routes of access will have to be incorporated into higher education provision (HEA, 2012, p.3). This increased flexibility will be required not only to provide 'second chance' education to adults who, due to family, work and other commitments cannot attend fulltime or part-time on-campus, but also for the increasing number of the Irish labour force, who require re-skilling/up-skilling and continued professional development (Delaney \& Fox, 2012).

\section{Participation in university education}

Successful completion of higher education has long been held as significant in conferring job opportunity, security and status on participants (Thomas \& Quinn, 2007). While participation in Irish campus based full-time higher education has grown steadily over recent years, research indicates that certain groups continue to be under-represented; namely those from lower socioeconomic backgrounds and adults over 23 years of age (Harmon \& Foubert, 2011). While the focus of this paper is on Ireland, social class also remains one of the most significant determinants of whether or not an individual will participate in higher education in England, Scotland and the United States (Chowdry et al., 2013; Ianelli, 2011; Piketty, 2014). Despite this, the issue of class in research has virtually disappeared (Field \& Morgan-Klein, 2013; Hooks, 2000; Nesbit, 2006). Nesbit (2006) challenges us to re-position class at the centre of discussions on inequality.

Some theorists argue that increased participation in full-time higher education will inevitably result in an increase in social inclusion (Gorard, 2008). However inequalities can nevertheless be reproduced, in terms of course level, field of study and institutional status (Fleming \& Finnegan, 2011; Ianelli, 2011). The abolition of Irish university tuition fees for undergraduates in 1996 facilitated middle class families to invest more heavily in second level education (Lynch, 2006). The net result of this is that young people from higher socio-economic groups perform better in the competition for university places than those from working class backgrounds (Denny, 2010). Participation at higher education by those from lower socio-economic backgrounds is therefore likely to be low or characterised by involvement in lower status courses (Fleming \& Finnegan, 2011), for example at level 6 (certificate) or 7 (diploma/ordinary degree), where the required points for entry are lower. This also holds true in the US, Scotland and England where working class students are more likely to attend lower status institutions on leaving compulsory education (Alon, 2009; Gallacher, 2009; Sutton Trust, 2010). Where the increase in higher education participation is for qualifications below degree level this can be problematic, as it is felt that the normal arguments relating to the benefits of higher education are 'usually based on more 
traditional undergraduate degree courses' (Gorard, 2008, p.427). Additionally, in the current Irish economy those with honours degree qualifications (level 8), or higher, find it easiest to obtain employment. The possibility of economic mobility therefore, from lower level courses, is often slight as they tend to have a low value in the labour market.

\section{The profile of distance education students}

Research on distance education student characteristics tends to focus primarily on psychological characteristics with a bias towards quantitative studies measuring the relationship between psychological variables (Carnoy et al., 2011; Coldwell et al., 2008; Qureshi et al., 2002). Research on demographic characteristics, such as social class, is somewhat neglected.

Where demographic research has been carried out, findings are more or less consistent; distance students in higher education are generally older than their full-time, on campus, counterparts, are more likely to be employed full-time and have family/financial commitments (Brown et al., 2013; Carnoy et al., 2012; Holmberg, 2005; Stöter et al., 2014). However, they are as a group getting younger (Guiney, 2014; Maclean, 2004).

That distance students are not necessarily new to higher education is noted in a number of studies (Halsne \& Gatta, 2002; Stöter et al., 2014). However, it is unclear whether the students in these studies are undergraduate or postgraduate, whether they had previously successfully completed an award, or what the level of that award was. Therefore, information which might be significant in relation to previous education attainment, and in a related sense to social class, remains hidden.

Although socio-economic background, as a demographic variable, is underexplored in the literature some studies do address it indirectly. Qureshi et al's (2002) Canadian study found that distance students were less motivated than full-time students. The annual income of the majority of students in both learning formats (i.e. on-campus and distance) was similar. The distance students were more likely to be working full-time and married with dependents, while the fulltime students (with a similar income) were younger, unlikely to be working full-time or have dependents. It seems unsurprising that, in such circumstances, the distance students struggled with motivation. This study speaks silently of social class.

Other studies are more direct in their reference to socio-economic background. Holmberg (2005) comments that distance study contributes to upward social mobility. Priebe et al's (2008) study on 'first generation students' found that distance education appears to attract a much higher proportion of students whose parents had not attended higher education. Brown et al. (2013) in their 'lived experience' study point out that distance students tend to be from a lower socioeconomic background and are often Maori. Stöter et al's (2014) research from Germany identified socio-economic background as a differentiating factor between distance and oncampus students in tertiary education, with distance students more likely to have a lower socioeconomic status. Bray et al. (2007, p.894) called for more empirical evidence regarding access to higher education, stating that there was 'little empirical evidence, positive or negative, of the ability of distance education to address these (i.e. access) problems' (my parenthesis).

\section{Methodology}

This article contributes to literature on distance graduates' socio-economic profile.

For this study a web-based survey was designed using a mix of twenty-one closed and open questions. A 5-point Likert scale was employed for 8 questions (104 sub questions), with respondents choosing between two extremes of a continuum. The survey was piloted to ensure 
clarity of questions, to confirm the time it would take to complete and whether it was running accurately and consistent in all popular web browsers.

The survey was sent to two hundred and twenty seven (227) recent (2012 and 2013) distance graduates. Eighty two (82) graduates responded to the survey representing a thirty six per cent $(36 \%)$ response rate. Descriptive analysis employing SPSS was carried out on the data. In certain instances the survey data is supplemented by data from institutional archived records, where this is available and appropriate to employ. Institutional data is employed in Table 2 to provide the prior education of all 158 distance graduates who exited with an honour (level 8) primary degree. Table 3, relating to gender, age and degree type, is also constructed from institutional records and provides data on all graduates, not just respondents to the survey.

Access to DCU distance programmes is open, with no minimum entry requirements for those over 23 years of age (those under 23 must meet the minimum entry requirements of the university). The minimum timeframe for completion of bachelor degrees (level 8) is three or four years and the maximum timeframe is normally eight years. The minimum timeframe for completion of master's degrees (level 9) is two years and the maximum timeframe is four years. As students take varying lengths of time to complete their degrees, graduate figures are not compared to registration figures in any specific year in this study.

The socio-economic classifications employed in this research are those used by the Irish Central Statistics Office (CSO). While there is no widely agreed definition of social class, occupation and education attainment remain the most widely used indicators.

\section{Findings and discussion}

\section{Socio economic background}

When determining the socio-economic background of full-time students we look at the social class and educational attainment of their parents. In order to contextualise this DCU study, parental social class (Table 1) and parental highest education attainment (Table 2) were examined.

Data on the socio-economic profile of Irish graduates is not systematically gathered. Therefore, it was not possible to draw comparisons between distance graduates and graduates from full-time study. However, data is gathered on the socio-economic background of new entrants to full-time higher education (the number of low socio-economic background students who graduate is likely to be lower than the number who enter (Furlong \& Cartmel, 2005) as this cohort often experience problems with persistence). While the figures reported in this paper represent a relatively small group of distance graduates, nevertheless some interesting insights can be gained by comparing them with the socio-economic background of new entrants to higher education.

The largest socio economic group of distance graduate respondents $(30 \% \mathrm{~N}=25)$ came from a background in which their father was a Skilled Manual worker (Table 1 refers). In contrast, the largest socio-economic group (18.9\%) of new entrants to full-time university in 2011/12 is Employer and Manager. The National Plan for Equity of Access to higher education (HEA, 2010, p.21), when examining participation in full-time higher education, identifies 'persistently low participation in higher education by students from low to middle income backgrounds'. Although the social class categories do not exclusively reflect bands of income, categories of 'Skilled Manual' and below tend to fall into the low to middle income bracket. For the distance graduate respondents in my study the highest participation is by those from low to middle income backgrounds $(54 \% \mathrm{~N}=44)$. Fifty three per cent $(53 \% \mathrm{~N}=43)$ of respondents categorised their mother as a 'Homemaker', a category of unpaid work. 
Table 1: Social class

\begin{tabular}{|l|c|c|c|c|}
\hline Social class & $\begin{array}{c}\text { Respondent } \\
\text { \% N }\end{array}$ & $\begin{array}{c}\text { Distance Grads. } \\
\text { Respondent's father } \\
\mathbf{\%} \text { N }\end{array}$ & $\begin{array}{c}\text { Respondent's } \\
\text { mother } \\
\mathbf{\%} \text { N }\end{array}$ & $\begin{array}{c}\text { Full-time university } \\
\text { new entrants } \\
\text { background } \\
\text { (2011/12) ** }\end{array}$ \\
\hline Employer/manager & $10 \%(8)$ & $12 \%(10)$ & $4 \%(3)$ & $18.9 \%$ \\
\hline Higher professional & $44 \%(36)$ & $23 \%(19)$ & $6 \%(5)$ & $11.0 \%$ \\
\hline Lower professional & $32 \%(26)$ & $7 \%(6)$ & $17 \%(14)$ & $9.3 \%$ \\
\hline Non-manual & $9 \%(7)$ & $4 \%(3)$ & $5 \%(4)$ & $9.3 \%$ \\
\hline Skilled manual & $1 \%(1)$ & $30 \%(25)$ & $5 \%(4)$ & $11.9 \%$ \\
\hline $\begin{array}{l}\text { Semi-skilled } \\
\text { manual }\end{array}$ & $1 \%(1)$ & $8 \%(7)$ & $4 \%(3)$ & $5.5 \%$ \\
\hline Unskilled manual & $0 \%$ & $4 \%(3)$ & $4 \%(3)$ & $2.4 \%$ \\
\hline $\begin{array}{l}\text { Own account } \\
\text { worker }\end{array}$ & $3 \%(3)$ & $3 \%(2)$ & $55 \% *(46)$ & $8.4 \%$ \\
\hline Farmer & $0 \%$ & $9 \%(7)$ & $0 \%$ & $7.6 \%$ \\
\hline Agricultural worker & $0 \%$ & $0 \%$ & $0 \%$ & $0.8 \%$ \\
\hline Unknown & & & & $15.0 \%$ \\
\hline
\end{tabular}

* $53 \%$ of respondents indicated that they had interpreted 'own account worker' as 'homemaker'.

$* *$ Base number $=20,692$, response rate $=87 \%$. These figures are for new entrants to full-time Irish university, not graduates. Source HEA (2013) Key Facts and Figures 2011/12 p.86

Piketty (2014, p.484) defines social mobility as 'the intergenerational correlation of education and earned incomes, which measures the reproduction of the skill hierarchy over time.' Social mobility is often interpreted as 'achieving a job of higher status' than that held by parents (Byrom \& Lightfood, 2013, p.814). If we measure social class by occupation (Ianelli, 2011) table 1 indicates that graduates' current social class is regularly higher than their social class of origin as represented by parental occupation. Further research is required to assess the extent to which this mobility is related to their distance education achievements.

The likelihood that new distance learners will be from lower socio economic backgrounds appears strong. This is consistent with the literature which finds that older graduates are more likely to be from lower socio economic backgrounds and have delayed their participation in higher education for reasons related to social class (Brine \& Waller, 2004; Croxford \& Raffe, 2014). Students from lower socio-economic backgrounds are regarded as 'at risk' in full time higher education resulting in a great deal of targeted support being made available to them. For example, in DCU, access students complete a four day, compulsory orientation programme at the start of their first year in which they are provided with intensive skills based workshops, meet staff and are assigned to an established access student who acts as their leader for the duration of the programme. Additionally, they are assigned a Project Officer who meets them on a one to one regular basis throughout their first year to ensure they are aware of, and able to access the supports they need. Universities inevitably prioritise support to the students they are funded to support. Whilst recognising that this type of support is costly to provide, targeted personalised support, modelled on the type of support full-time 'at risk' students receive, seems key to the chances of success for new distance learners. 


\section{Highest education attainment in full-time education}

Parental education is a significant factor when deciding to proceed to higher education (Flannery \& O'Donoghue, 2009). The 2011 Irish census of population tells us that young people with neither parent educated beyond primary school level are very unlikely to attend full time higher education (CSO, 2012, p.22). In comparison, the largest single group $(28 \% \mathrm{~N}=23)$ of distance graduate respondents were from backgrounds in which the full time education of their father had stopped at primary level or included no formal education (Table 2 refers). Additionally, recent survey data from the HEA states that just 19\% of full-time higher education student's parent's highest qualification is low secondary level or below (Harmon \& Foubert, 2011, p.21). For survey respondents in my study, fifty-six per cent $(56 \% \mathrm{~N}=45)$ of their fathers and forty-six per cent $(46 \% \mathrm{~N}=38)$ of their mothers fell into this category. Figures indicate that $84 \%(\mathrm{~N}=69)$ of respondents attained a higher level of education than their parents.

With regard to the graduates themselves, it was possible to construct a picture of the previous highest educational attainment in full-time education of all level 8 graduates $(\mathrm{N}=158)$ from archival records (Table 2 refers). This exercise was completed only for level 8 graduates since those who undertake level 9 qualifications are normally required to hold a level 8 degree. Thirty nine per cent $(39 \% \mathrm{~N}=62)$ of all level 8 online distance graduates had finished their full-time education at second level and had never previously accessed any form of higher education. For this group, distance higher education is truly broadening access to Irish university education. We know from sociology theory that people act as a result of societal structures rather than simply for reasons (Bourdieu \& Passeron, 1977; Brubaker, 2004; Ianelli, 2011). Despite funding, certain groups in society may not avail of full-time higher education due to their social class habitus. For such groups the availability of flexible study options, where they can work and study at the same time, are likely to be very important.

Surprisingly, a further thirty nine per cent $(39 \% \mathrm{~N}=62)$ of the total number of level 8 graduates had completed some form of full-time third level qualification (certificate or diploma/ordinary degree) prior to completing their level 8 distance honours degree. This group are also worthy of note. Unlike previous generations, for this group of working class students full time higher education is on their radar. $24 \%(\mathrm{~N}=15)$ of this group met the normal university entry requirements on completion of their second level studies, so were deemed capable of university study. However, because of the competition for university places, they did not secure enough points to be offered a full-time university place and instead take a place on a lower level course. The HE funding mechanism, and resulting competition for university places, appears to be funnelling many working class students, capable of university study, into lower status full-time courses and subsequent delayed participation in university education. If these students wish to top up their lower qualification they must commit to further full-time study, an option not often open to working class students whose parents/guardians are often anxious for them to enter the work force and begin to support themselves financially. The only other option open for further study is part-time or distance learning.

The provision of a broad range of full and top up degree programmes to facilitate new distance learners is important. Funding to develop flexible course provision, within and between providers, is essential in order to maintain and develop access to university education for this cohort of learners. 
Table 2: Highest attainment in full-time education

\begin{tabular}{|l|c|c|c|c|c|}
\hline & $\begin{array}{c}\text { Distance } \\
\text { Graduates* }\end{array}$ & \multicolumn{2}{|c|}{$\begin{array}{c}\text { Distance graduate's } \\
\text { father** }\end{array}$} & \multicolumn{2}{|c|}{$\begin{array}{c}\text { Distance graduate's } \\
\text { mother** }\end{array}$} \\
\hline $\begin{array}{l}\text { Highest full-time } \\
\text { education attained }\end{array}$ & $\begin{array}{c}\text { Level 8 } \\
\text { All Graduates } \\
\text { \% (N) }\end{array}$ & $\begin{array}{c}\text { Level 8 } \\
\text { Respondents } \\
\text { \% (N) }\end{array}$ & $\begin{array}{c}\text { Level 9 } \\
\text { Respondents } \\
\text { \% (N) }\end{array}$ & $\begin{array}{c}\text { Level 8 } \\
\text { Respondents } \\
\text { \% (N) }\end{array}$ & $\begin{array}{c}\text { Level 9 } \\
\text { Respondents } \\
\%(\mathbf{N})\end{array}$ \\
\hline Primary*** & $0 \%$ & $18.5 \%(15)$ & $9.9 \%(8)$ & $12.3 \%(10)$ & $4.9 \%(4)$ \\
\hline Lower secondary & $6 \%(9)$ & $18.5 \%(15)$ & $8.6 \%(7)$ & $21.0 \%(17)$ & $8.6 \%(7)$ \\
\hline Upper secondary & $33 \%(52)$ & $7.4 \%(6)$ & $12.3 \%(11)$ & $14.8 \%(12)$ & $14.8 \%(13)$ \\
\hline $\begin{array}{l}\text { Third level non- } \\
\text { degree }\end{array}$ & $39 \%(62)$ & $6.2 \%(5)$ & $2.5 \%(2)$ & $7.4 \%(6)$ & $3.7 \%(3)$ \\
\hline $\begin{array}{l}\text { Third level degree } \\
\text { or higher } \\
\text { Not given }\end{array}$ & $\begin{array}{c}6 \%(9) \\
16 \%(26)\end{array}$ & $12.3 \%(10)$ & $3.7 \%(3)$ & $7.4 \%(6)$ & $4.9 \%(4)$ \\
\hline Total & $100 \%(158)$ & $62.9 \%(51)$ & $37.0 \%(31)$ & $62.9 \%(51)$ & $37.0 \%(31)$ \\
\hline
\end{tabular}

*Figures in this column are for all level 8 distance graduates

**Figures for survey respondents only

*** including no formal education

\section{Gender, degree type and age}

The majority $(65 \% \mathrm{~N}=148)$ of the two hundred and twenty seven graduates were male (Table 3 refers). This differs somewhat from Irish (Darmody \& Fleming, 2009) and international research (Brown et al., 2013; Callender et al., 2006) on part-time and distance students which indicates that women are more likely to participate. Overall, however, the finding is consistent with international research confirming that males are more likely to participate in Information Technology related degrees (Carnoy et al., 2012; Coldwell et al., 2008). Female participation was more prevalent on the $\mathrm{BA}$ degree while male participation dominated the $\mathrm{BSc}$ and $\mathrm{MSc}$ programmes which are technology related.

Most graduates $(68 \% \mathrm{~N}=158)$ had completed a level 8 honours bachelor's degree, with the remaining graduates completing a level 9 postgraduate/masters' degree. Evidence from both Australia (Birch et al., 2009) and New Zealand (Smyth \& Strathdee, 2010) indicate that the subject studied, more than any other factor, is likely to be a key determinant of future earnings with those graduating with elite vocational degrees (e.g. nursing, engineering) performing best in the labour market. While there are of course resource implications, provision of distance degrees of this type will likely enhance mobility prospects for new distance learners.

International research points to the fact that distance students are generally older than on-campus students. The DCU data is again consistent with international findings. The majority (79\% $\mathrm{N}=179$ ) of graduates were in the 30-49 age groups (Table 3 refers), an age group underrepresented in full-time higher education. That distance students are, as a group, getting younger could not be confirmed by the DCU data, as it has not been analysed for a sufficiently long period of time. (The gender, age and programme of study weighting were reflected in the response rate to the survey.)

The evidence from the DCU data suggests that the relationship between age and participation in distance education relates to socio-economic background. Students from lower socio economic groups often wait until they can fund participation in distance university education themselves or until they are well established in an employment where their employer will assist with funding. The problem with late participation is that it comes when new distance learners have many 
demands on their time, in terms of work and family commitments (Kember, 1995; Simpson, 2002; Tinto, 1993; Woodley, 2004). This in turn impacts on retention.

A policy which funds all students equally, regardless of mode of delivery, would likely support earlier participation of new distance learners which in turn could support their persistence. Distance education too can (re)envision itself as a viable option for university education for young working class adults.

Table 3: All distance graduates in this study by gender, age at graduation and degree type

\begin{tabular}{|l|c|c|c|c|c|}
\hline Characteristic & $\begin{array}{c}\text { BA } \\
\text { (level 8) } \\
\text { \% (N) }\end{array}$ & $\begin{array}{c}\text { BSc } \\
\text { (level 8) } \\
\text { \% (N) }\end{array}$ & $\begin{array}{c}\text { MSc } \\
\text { (level 9) } \\
\text { \% (N) }\end{array}$ & $\begin{array}{c}\text { Total } \\
\%\end{array}$ & $\begin{array}{c}\text { Base number } \\
\text { (N) }\end{array}$ \\
\hline \multicolumn{6}{|c|}{ Gender } \\
\hline Male & $20(45)$ & $20(45)$ & $25(58)$ & 65 & 148 \\
\hline Female & $29(66)$ & $1(2)$ & $5(11)$ & 35 & 79 \\
\hline Total & $49(111)$ & $21(47)$ & $30(69)$ & 100 & 227 \\
\hline \multicolumn{6}{|c|}{ Age } \\
\hline $18-29$ & $3(6)$ & 0 & $2(5)$ & 5 & 11 \\
\hline $30-39$ & $17(39)$ & $13(29)$ & $14(32)$ & 44 & 100 \\
\hline $40-49$ & $18(40)$ & $6(13)$ & $11(25)$ & 35 & 79 \\
\hline $50-59$ & $6(14)$ & $2(5)$ & $3(7)$ & 11 & 25 \\
\hline $60+$ & $5(12)$ & 0 & 0 & 5 & 12 \\
\hline Total & $\mathbf{4 9 ( 1 1 1 )}$ & $\mathbf{2 1 ( 4 7 )}$ & $\mathbf{3 0 ( 6 9 )}$ & $\mathbf{1 0 0}$ & $\mathbf{2 2 7}$ \\
\hline
\end{tabular}

\section{Employment, fee payment and location}

Needing to work or be available for work presents a significant barrier to accessing full-time education and was the primary reason given by graduates for choosing to study by online distance education (Figure 1 refers). The majority of distance graduate respondents were in full-time employment $(74 \% \mathrm{~N}=61)$ and had dependent children $(62 \% \mathrm{~N}=51)$. Eighty per cent $(\mathrm{N}=66)$ of respondents rated not being able to afford to give up their job as 'relevant' to studying online while sixty-eight per cent $(N=56)$ rated wanting to work full time as 'relevant' to them. The second most prevalent reason for choosing online distance higher education was the amount of control it gave participants over their own time management. While mature students are often intrinsically motivated by an interest in the course topic, they tend to be overridingly interested in enhancing their employment opportunities (Purcell et al., 2007; Redmond, 2006; Stocke, 2007). Credential inflation too can have an impact on participation with adults feeling they must upgrade their qualifications in order to sustain labour market competitiveness (Woodley \& Wilson, 2002).

While a narrative of disadvantage often surrounds mature student participation in higher education the fact that the majority of graduates in this DCU study are in full-time employment give grounds for optimism. It also ties in with recent research from Woodfield (2011 p.409) who, employing data from the Higher Education Statistical Agency (UK reference: 27322) found that mature graduates are in fact advantaged in the graduate labour market. Notably, they more frequently secured graduate-level work and a higher salary. Strategies which highlight such outcomes and engage students in valuing their existing life and work experience (Thomas \& Jones, 2007) together with connecting them with successful distance alumni would likely benefit new distance learners.

Online distance education provides more flexibility than part-time education which is important to those who work long hours or have family commitments which militate against them 
committing to attend courses at specific times each week. Most significantly, eighty six per cent $(86 \% \mathrm{~N}=71)$ of respondents either strongly agreed $(51 \% \mathrm{~N}=42)$ or agreed $(35 \% \mathrm{~N}=29)$ that given their circumstances, they could not have completed a degree any other way.

'With a full time job and a family I needed flexibility when completing my college work.'

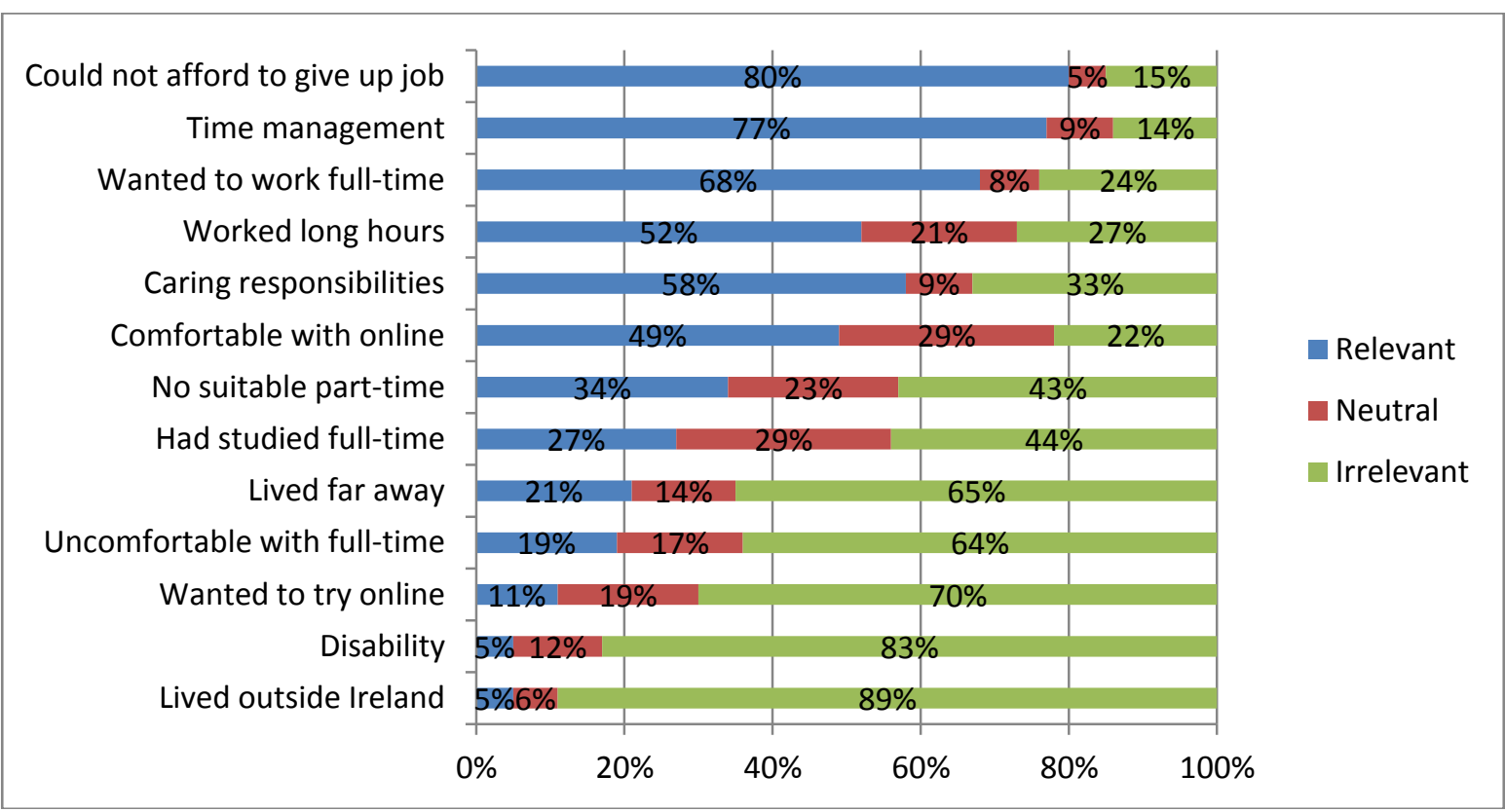

Figure 1. Reasons, ranked by relevance, contributing to the decision of respondents to study by online distance education

Overall, distance graduate respondents in this DCU study pay their own fees with some help from employers (Table 4 refers). Employers were more likely to pay fees for those undertaking a BSc or MSc degree than a BA degree. This finding would appear to indicate a willingness on the part of employers to support the education of their employees where it relates to their field of work. It seems likely that, in the absence of state funding, periods of economic recession and resulting high unemployment will impact negatively on participation rates in distance education.

Distance graduate respondents in this study are primarily Irish (Table 4 refers), with a large minority located in Dublin while completing their studies $(36 \% \mathrm{~N}=30)$. Students often choose distance education simply to accommodate their busy lives and to give them more control over their own time management (Delaney \& Fox, 2012).

However, the majority of distance graduates in this study were widely dispersed across fifteen counties outside Dublin (Ireland consists of 32 separate counties) with a small number based in Europe (five; and all Irish). Previous studies found that distance students were more likely to be time-bound rather than place bound (Latanich et al., 2001; Livertos \& Franks, 1996; Simpson, 2002). In this DCU study, students presented as more restricted by place. Alternatively, this finding may indicate a preference for the institution (DCU) over institutions more local to the students. Further research is required in this regard.

In 2013 approximately $€ 350$ million was required to fund the system of maintenance grants for Irish higher level full time students who lived away from home (Oireachtas report, 2013). Research has shown that the costs associated with travelling, or having to live away from home while studying, present a significant barrier to accessing full-time higher education for many students, in particular those from lower socio-economic backgrounds (Cullinan et al., 2013; McCoy et al., 2010). Factors relating to affordability were key to why distance graduates choose 
to study by online distance education (Figure 1 refers); not the affordability relating to participation costs but rather the affordability relating to opportunity costs as they need to be able to work and study at the same time. Online distance education can help overcome the barrier to access which travel, accommodation and other costs present.

Table 4: Socio-economic characteristics of survey respondents

\begin{tabular}{|c|c|c|c|c|c|}
\hline Characteristic & $\begin{array}{c}\text { BA } \\
\%(N)\end{array}$ & $\begin{array}{c}\text { BSc } \\
\%(N)\end{array}$ & $\begin{array}{l}\text { MSc } \\
\%(N)\end{array}$ & $\begin{array}{c}\text { Total } \\
\%\end{array}$ & $\begin{array}{c}\text { Base number } \\
\mathrm{N}^{*}\end{array}$ \\
\hline \multicolumn{6}{|c|}{ Nationality } \\
\hline Irish & $44(36)$ & $15(12)$ & $37(30)$ & 96 & 78 \\
\hline Other EU/EEA & $4(3)$ & 0 & 0 & 4 & 3 \\
\hline Non EU/EEA & 0 & 0 & 0 & 0 & \\
\hline \multicolumn{6}{|c|}{ Location } \\
\hline Dublin & $20(16)$ & $2(2)$ & $14(11)$ & 36 & 29 \\
\hline Outside Dublin & $25(20)$ & $12(10)$ & $21(17)$ & 58 & 47 \\
\hline Outside Ireland & $2(2)$ & 0 & $4(3)$ & 6 & 5 \\
\hline \multicolumn{6}{|l|}{ Dependent Children } \\
\hline Yes & $28(23)$ & $9(8)$ & $25(20)$ & 62 & 51 \\
\hline No & $19(15)$ & $5(4)$ & $14(11)$ & 38 & 30 \\
\hline \multicolumn{6}{|c|}{ Employment Status } \\
\hline In full-time employment & $24(20)$ & $13(11)$ & $37(30)$ & 74 & 61 \\
\hline In part-time employment & $9(7)$ & 0 & $1(1)$ & 10 & 8 \\
\hline Seeking employment & $5(4)$ & $1(1)$ & 0 & 6 & 5 \\
\hline Undertaking further study & $6(5)$ & & & 6 & 5 \\
\hline Not available for employment & $4(3)$ & & & 4 & 3 \\
\hline \multicolumn{6}{|c|}{$\begin{array}{ll}\text { Primary fee payer } \\
\end{array}$} \\
\hline Employer & $5(4)$ & $11(9)$ & $17(14)$ & 33 & 27 \\
\hline Family/friends & $1(1)$ & 0 & $1(1)$ & 2 & 2 \\
\hline Self & $41(33)$ & $4(3)$ & $20(16)$ & 65 & 52 \\
\hline
\end{tabular}

* One respondent did not reply to questions related to Nationality, Location, Dependent Children and Primary fee payer.

\section{Conclusion}

In the early $21^{\text {st }}$ century distance education continues to have an important social justice role in facilitating a broadening and deepening of access to university education and contributing to social mobility. Despite increasing participation rates in full-time higher education, inequalities continue to be reproduced. Those from lower socio-economic backgrounds are less likely to participate and when they do, they are more likely to participate in lower level courses. This is problematic as the benefits of higher education normally relate to traditional degree programmes. Furthermore the possibility of economic mobility from low level courses is slight due to their low value in the labour market.

Graduates in this study were primarily from groups who are under-represented in full-time university education; namely adults from lower socio-economic backgrounds. For some it was their first opportunity to access higher education. For others, who had already accessed full-time higher education at a lower level, it allowed them to upgrade and achieve an honours degree and the associated enhanced employment and life opportunities. Limitations of this study include the sample size and the fact that data is self-reported. Nevertheless the importance of this study lies in highlighting, within this sample of graduates, the diversity of distance learners who are a much more heterogeneous group than on-campus students, in terms of socio-economic background 
and prior educational experience (Bates, 2014). Additionally, the importance of socio-economic background in better understanding distance learners is emphasised.

This research has contributed to the existing body of knowledge on distance graduates. Knowledge of distance graduates allows us to reflect on the role of distance education. As one of the primary purposes of public funding for higher education is to improve social mobility (Piketty, 2014) the data in this study provides important evidence for policy makers on the role distance education can play in furthering that agenda. Knowing who our graduates are allows us, as course providers, to speak more confidently about our role in broadening access, to champion the cause of our students and so do things better for first-time distance learners.

\section{References}

1. Alon, S. (2009). The evolution of class inequality in higher education: competition, exclusion and adaptation. In American Sociological Review, 74(5), (pp. 731-55).

2. Bates, T. (2014). Feedback to the author at EDEN Research Workshop 8, Oxford UK.

3. Birch, E.-R.; Li, I. and Miller, P. (2009). The influences of institution attended and field of study on graduates' starting salaries. In The Australian Economic Review, 42(1), (pp. 42-63).

4. Bourdieu, P. and Passeron, J.C. (1977). Reproduction in Education, Society and Culture. (R. Nice, Trans.) London: Sage Publications.

5. Bray, N.J.; Harris, M.S. and Major, C. (2007). New verse of the same old chorus?: looking holistically at distance education research. In Research in Higher Education, 48(7), (pp. 889-908).

6. Brine, J. and Waller, R. (2004). Working-class women on an access course: Risk, opportunity and (re) constructing identities. In Gender \& Education, 16(1), (pp. 97-113).

7. Brown, M.; Hughes, H.; Keppell, M.; Hard, N. and Smith, L. (2013). In their own words: Student stories of seeking learning support. In Open Praxis, 5(4), (pp. 345-354).

8. Brubaker, R. (2004). Rethinking classical theory: The sociological vision of Pierre Bourdieu. In D. Swartz \& V.L. Zolberg (eds.), After Bourdieu: influence, critique, elaboration. The Netherlands: Kluwer Academic Publishers.

9. Byrom, T. and Lightfoot, N. (2013). Interrupted trajectories: the impact of academic failure on the social mobility of working-class students. In British Journal of Sociology of Education, 34(56), (pp. 812-828).

10. Callender, C.; Wilkinson, D. and Mackinon, K. (2006). Part-time Study in Higher Education in Wales: A survey of students' attitudes and experiences of part-time study and its costs 2005/6. London South Bank University, Policy Studies Institute.

11. Carnoy, M.; Rabling, B.; Castano-Munoz, J.; Duart Montilou, J. and Sancho-Vinuesa, T. (2012). Who attends and completes virtual universities: the case of the Open University of Catalonia (UOC). In Higher Education, 63(1), (pp. 53-82).

12. Chowdry, H.; Crawford, C.; Dearden, L.; Goodman, A. and Vignoles, A. (2013). Widening participation in higher education: analysis using linked administrative data. In Journal of the Royal Statistical Society: Series A (Statistics in Society), 176(2), (pp. 431-457).

13. Coldwell, J.; Craig, A.; Paterson, T. and Mustard, J. (2008). Online students: relationships between participation, demographics and academic performance. In Electronic Journal e-learning, 6(1), (pp. 19-30). Accessed online $21^{\text {st }}$ June 2014 at http://www.ejel.org/volume6/issue1 
14. Croxford, L. and Raffe, D. (2014). Social class, ethnicity and access to higher education in the four countries of the UK: 1996-2010. In International Journal of Lifelong Education, 33(1), (pp. $77-$ 95).

15. CSO - Central Statistics Office (2012). Profile 9 - What we know. Dublin. Accessed online on $10^{\text {th }}$ April 2014 at

http://www.cso.ie/en/media/csoie/census/documents/census2011profile9/Profile,9,What, we,know,full,doc,for,web.pdf

16. Cullinan, J.; Flannery, D.; Walsh, S. and McCoy, S. (2013). Distance Effects, Social Class and the Decision to Participate in Higher Education. In Ireland Economic and Social Review, 44(1), (pp. 19-51).

17. Darmody, M. and Fleming, B. (2009). 'The balancing act' - Irish part-time undergraduate students in higher education. In Irish Educational Studies, 28(1), (pp. 67-83).

18. Delaney, L. and Fox, S. (2012). The role of distance education in broadening access to Irish higher education. In Higher Education Ireland ed. How Equal? Access to Higher Education in Ireland Higher Education Authority Ireland National Conference, $7^{\text {th }}$ November 2013; Royal Hospital Kilmainham, Dublin

19. Denny, K. (2010). What did abolishing university fees in Ireland do? University College Dublin: Geary Institute, Discussion Paper Series, School of Economics \& Geary Institute. Accessed September 2013 online at: http://www.ucd.ie/geary/static/publications/workingpapers/gearywp201026.pdf

20. Dublin City University (DCU) Access Report (2011). Celebrating success: 21 years of DCU Access service. Available online at: http://www4.dcu.ie/sites/default/files/students/pdfs/DCU_21Publication.pdf

21. EAN - European Access Network (2015). Constitution. Accessed online $20^{\text {th }}$ Dec. 2014 at: http://www.ean-edu.org/about-us.html

22. Field, J. and Morgan-Klein, N. (2013). Reappraising the importance of class in higher education entry and persistence. In Studies in the Education of Adults, 45(2), Autumn 2013, (pp. 162-176).

23. Flannery, D. and O'Donoghue, C. (2009). The Determinants of Higher Education Participation in Ireland: A Micro Analysis. In The Economic and Social Review, 40, (pp. 7-107).

24. Fleming, T. and Finnegan, F. (2011). Non-traditional students in Irish Higher Education- A research report. Available online at: http://www.ranlhe.dsw.edu.pl

25. Furlong, A. and Cartmel, F. (2005). Graduates from disadvantaged families: Early labour market experiences. York: Joseph Rowntree Foundation. Accessed online $2^{\text {nd }}$ Feb 2015 at http://www.jrf.org.uk/sites/files/jrf/1861347820.pdf

26. Gallacher, J. (2009). Higher education in Scotland's colleges: a distinctive tradition? In Higher Education Quarterly, 63(4), (pp. 349-69). London: Wiley.

27. Gorard, S. (2008). Who is missing from higher education? In Cambridge Journal of Education, 38(3), (pp. 421-437).

28. Guiney, P. (2014). Extramural students' participation and achievement: Trends, patterns and highlights.

New Zealand Ministry of Education. Accessed online $9^{\text {th }}$ June 2015 at

http://www.educationcounts.govt.nz/publications/ict/145699 
29. Halsne, A.M. and Gatta, L.A. (2002): Online versus traditionally-delivered instruction: A descriptive study of learner characteristics in a community college setting. In Online Journal of Distance Learning Administration, 5(1). Accessed online on $22^{\text {nd }}$ June 2014 at http://www.westga.edu/ distance/ojdla/spring51/halsne51.html

30. Harmon, D. and Foubert, O. (2011). Eurostudent Survey IV Report on the Social and Living Conditions of Higher Education Students in Ireland 2009/2010. Dublin: Higher Education Authority and Insight Statistical Consulting.

31. HEA - Higher Education Authority (2008). National Plan for Equity of Access to Higher Education 2008-2013, Dublin. Available online at http://www.hea.ie/content/2008-0

32. HEA (2010). National Plan for Equity of Access to Higher Education 2008-2013: Mid Term Review, HEA Dublin. Available online at http://www.hea.ie/sites/default/files/midterm_review_national_plan_of_equity_access_2008-2013.pdf

33. HEA (2012). Part-time higher education and training in Ireland: Current policy, practice and options for the future. Consultation paper, May 2012, HEA, Dublin.

34. HEA (2013). Higher Education Key Facts \& Figures 2011/2012. HEA, Dublin. Accessed online at http://www.hea.ie/en/Publications

35. Holmberg, B. (2005). The Evolution, Principles and Practices of Distance Education. Oldenburg: BISVerlag der Carl von Ossietzky Universität Oldenburg.

36. Hooks, B. (2000). Where We Stand: Class Matters. New York: Routledge.

37. Ianelli, C. (2011). Educational expansion and social mobility: the Scottish case. In Social Policy and Society, 10(2), (pp. 251-64). Cambridge: Cambridge University Press.

38. Kember, D. (1995). Open learning courses for adults: a model of student progress. Englewood Cliffs, NJ, Education Technology Publications.

39. Latanich, G.; Nonis, S.A. and Hudson, G.I. (2001). A Profile of today's Distance Learners: An investigation of Demographic and Individual difference Variables of Distance and NonDistance Learners. In Journal of Marketing for Higher Education, 11(3), (pp. 1-16).

40. Liviertos, B. and Franks, J. (1996). Alternative Learning Modes; Spring '92 Telecourse and Weekend College Enrolees. Columbia, MD: Howard Community College Office of Planning and Evaluation Research. (ERIC Document Reproduction Service ED 385 311).

41. Lynch, K. (2006). Neo-liberalism and marketisation: the implications for higher education. In European Educational Research Journal, 5(1), (pp. 1-17).

42. Maclean, S. (2004). Students turn to OU to avoid debt. In The Guardian, Monday 12 January 2004. Retrieved on $21^{\text {st }}$ June from http://www.theguardian.com/education/2004/jan/12/students.accesstouniversity

43. McCoy, S.; Calvert, E.; Smyth, E. and Darmody, M. (2010). Study on the Costs of Participation in Higher Education. Dublin: Higher Education Authority.

44. Medin, C.; Roy, S. and Ann, T. (1999). World Wide Web versus mail surveys: $A$ comparison and report. Paper presentation at ANZMAC99 Conference, Marketing in the Third Millennium, Sydney, Australia, accessed online at http://www.anzmac.org/conference_archive/1999/Site/papers.htm

45. Merriam, S.D. (1988). Case Study Research in Education: A Qualitative Approach. San Francisco: Jossey-Bass.

46. Nesbit, T. (2006). What's the matter with social class? In Adult Education Quarterly, 56(3), (pp. 171-87). Sage. 
47. Oireachtas (2013). Third Level Student Grant System: Discussion with SUSI (Continued). Accessed on $19^{\text {th }}$ June 2013 online at

http://oireachtasdebates.oireachtas.ie/debates\%20authoring/DebatesWebPack.nsf/committ eetakes/EDJ2013061900011

48. Piketty, T. (2014). Capital in the Twenty-First Century. Cambridge: The Belknap Press of Harvard University Press.

49. Priebe, L.C.; Ross, T.L. and Low, K.W. (2008). Exploring the Role of distance Education in Fostering Equitable University Access for First Generation Students: A phenomenological survey. In International Review of Research in Open and Distance Learning, 9(1), (pp. 2-12).

50. Purcell, K.; Wilton, N. and Elias, P. (2007). Hard lessons for lifelong learners? Age and experience in the graduate labour market. In Higher Education Quarterly, 61(1), (pp. 57-82).

51. Qureshi, E.; Morton, L.L. and Antosz, E. (2002). An interesting profile - University students who take distance education courses show weaker motivation than on-campus students. In Online Journal of Distance Learning Administration, 5 (4). Accessed online $20^{\text {th }}$ June 2014 at http://www.westga.edu/ distance/ojdla/winter54/Quershi54.htm

52. Redmond, P (2006). Outcasts on the inside: Graduates, employability and widening participation. In Tertiary Education and Management, 12(2), (pp. 119-135).

53. Simpson, O. (2002). Supporting students in online, open and distance learning. London: Kogan Page.

54. Smyth, R. and Strathdee, R. (2010). The effects of type of institution attended on graduate earnings in New Zealand: a cross-field comparison. In British Journal of Sociology of Education, 31(4), (pp. 489-508).

55. Stocke, V. (2007). Explaining Educational Decision and Effects of Families' Social Class Position: An Empirical Test of the Breen-Goldthorpe Model of Educational Attainment. In European Sociological Review, 23(4), (pp. 505-19).

56. Stöter, J.; Bullen, M.; Zawacki-Richter, O. and von Prümmer, C. (2014). From the Back Door into the Mainstream: The Characteristics of Lifelong Learners. In O. Zawacki-Richter \& T. Anderson (eds.), Online Distance Education: Towards a Research Agenda. Accessed online on $23^{\text {rd }}$ June 2014 at http://www.aupress.ca/index.php/books/120233

57. Sutton Trust, The (2010). Responding to the new landscape for university access. Accessed online Jan 2013 at http://www.suttontrust.com/researcharchive/responding-new-landscape-universityaccess/

58. Thomas, L. and Jones, R. (2007). Embedding Employability in the Context of Widening Participation. York: the Higher Education Academy.

59. Thomas, L. and Quinn, J. (2007). First generation entry into higher education: An international study. New York: McGraw Hill.

60. Tinto, V. (1993). Leaving college: Retbinking the causes and cures of student attrition. Chicago: University of Chicago Press.

61. Woodfield, R. (2011). Age and first destination employment from UK universities: Are mature students disadvantaged? In Studies in Higher Education, 36, (pp. 409-425).

62. Woodley, A. (2004). Conceptualising student drop-out in part-time distance education: Pathologising the normal? In Open Learning, 19, (pp. 48-63).

63. Woodley, A. and Wilson, J. (2002). British higher education and its older clients. In Higher Education, 44, (pp. 329-347). 


\section{Acknowledgements}

The author would like to thank Professor Mark Brown and Mr. Seamus Fox for facilitating this research. 